\title{
Comparative toxicity of four local botanical powders to Sitophilus zeamais and influence of drying regime and particle size on insecticidal efficacy
}

\author{
Elias Nchiwan NUKENINE ${ }^{1 *}$, Florence Pagou CHOUKA ${ }^{1}$, Michael Boboh VABI $^{2}$, \\ Christoph REICHMUTH ${ }^{3}$ and Cornel ADLER ${ }^{3}$ \\ ${ }^{I}$ Department of Biological Sciences, Faculty of Science, University of Ngaoundere, PO Box 454 Ngaoundere, \\ Cameroon. \\ ${ }^{2}$ Rural Sociologist and Former Staff of the Humid Forest Station, International Institute of Tropical Agriculture, \\ Yaoundé, Cameroon. \\ ${ }^{3}$ Federal Research Centre for Cultivated Plants - Julius Kühn - Institut, Institute for Ecological Chemistry, \\ Plant Analysis and Stored Product Protection, Königin-Luise-Str. 19, D-14195 Berlin, Germany. \\ *Corresponding author, E-mail: elinchiwan@yahoo.fr, ennukenine@fulbrightmail.org;
} Tel. $0023722254060 / 0023779598655$.

\begin{abstract}
The toxicity of Azadirachta indica seed powder and leaf powders from Plectranthus glandulosus, Steganotaenia araliacea and Annona senegalensis to adult Sitophilus zeamais was determined in the laboratory. The influence of drying regime and particle size on the insecticidal efficacy of $P$. glandulosus and $S$. araliacea powders was also assessed. The seeds and leaves were either dried under shade or sunlight, pulverized until the particles passed through a $1 \mathrm{~mm}$ or $0.2 \mathrm{~mm}$ mesh-sieve. Maize grains were admixed with the powders at the rates $0,5,10,20$ and $40 \mathrm{~g} / \mathrm{kg}$ for the assessment of mortality over a $14-\mathrm{d}$ or $30-\mathrm{d}$ period, as well as for population increase and damage. Within 14-d exposure, P. glandulosus powder caused the highest weevil mortality followed by A. indica. A. indica powder was by far more effective in reducing grain damage and population increase compared with all the other powders during three-month storage period. Powders from the leaves dried under shade compared with those dried under sunlight and the smaller compared with the larger particle size, caused higher weevil mortality. Neem seed powder and powdered leaves of $P$. glandulosus have a great potential in the protection of maize against $S$. zeamais infestation in subsistence storage systems.
\end{abstract}

(c) 2013 International Formulae Group. All rights reserved.

Keywords: Plant products, storage pest, maize, infestation, Cameroon.

\section{INTRODUCTION}

Maize (Zea mays L., Poaceae) is an important cereal widely cultivated in the tropics; both for human consumption and livestock feed. It is the most important cereal in the world, Africa and Cameroon in terms of total production (FAO, 2011). In Africa, the constant availability of maize in adequate quantities is fundamental to food security. Unfortunately, increasing the supply of the crop is marred by losses during storage caused principally by insects. Among these insects, 
the cosmopolitan Sitophilus zeamais Motschulsky (Coleopera: Curculionidae) is one of the most destructive (Reichmuth et al., 2007). The weevil together with other insects cause an estimated $24.5 \%$ loss of maize, and damaged grains have reduced nutritional value and weight, low frequency of germination, and low market value (Yuya et al., 2009; Tefera et al., 2011: Napoleao et al., 2013). Nukenine et al. (2002) recorded mean percentage damaged grains caused by $S$. zeamais of $33 \%$ on maize stored in the Adamawa Region of Cameroon.

A commonly used method for controlling pests in stored products is the application of synthetic contact insecticides (Chaube, 2008). This has led to problems such as pest resurgence and increasing costs of application originating from the development of resistance to insecticides (Zhao et al., 2012). In addition these pesticides can have lethal effects on non-target organisms and can cause direct toxicity to applicators (Philips and Throne, 2010). These drawbacks of synthetic insecticides have stimulated intensive search for alternative measures that are safer and environmentally friendly (Isman, 2006; Obeng-Ofori, 2007). Among potential natural reduced-risk pesticides are botanical insecticides, which are products based on powders, extracts or purified substances of plant origin.

Most of the grain produced in subSaharan Africa comes from small-scale farmers, many of whom use different plant products for insect control (Jembere et al., 1995; Tapondjou et al., 2000; Ukeh et al., 2012). Recently, the use of these natural materials has stimulated research to establish the scientific basis targeting their efficacy, active constituents and effective application technologies (Jembere et al., 1995; Nukenine et al., 2007). The publications on plants or plant products used in storage against different storage insect pests are dominated by essential oils, pure compounds or solvent extracts, with very little on powdered materials. None of these dominant approaches account for the real life situations of resourcelimited farm-families, who are more familiar with simple methods for preparing botanicals (dried materials, and in some cases powdered form) (Paul et al., 2009). Jembere et al. (1995) and Weaver and Subramanyam (2000) reported that powdering considerably enhance the effectiveness of traditional practice of adding intact, fresh leaves to stored commodities. As a corollary, smaller particles of plant materials compared to larger ones may be more effective against insect pests. The efficacy of the powdered seeds of Piper guineense with smaller particles $(0.6 \mathrm{~mm})$ against $S$. zeamais on maize was comparable with that of Pirimiphos Methyl, while the larger particles $(2 \mathrm{~mm})$ were ineffective (Asawalam and Emosairue, 2006).

Azadirachta indica A. Juss (Meliaceae) is an Indian tree, commonly called neem. It has many useful compounds, including azadirachtin, a tetranotriterpenoid limonoid, the active ingredient in many neem-based insecticides (Mordue and Blackwell, 1993). It possesses antifeedant, repellant, growth disrupting and larvicidal properties against a large number of pests (Mathur, 2013). The neem plant was introduced in Cameroon in 1947 (Yengué and Callot, 2002), and is widely distributed in the northern partand increasingly, in few areas in the south. Unfortunately, little is known about the use of this plant in Cameroon against insect pests , while its use in the treatment of diseases is common and has been on the rise (Noumi and Anguessin, 2010).

The leaves of Plectranthus glandulosus Hook f. (syn. Coleus laxiflorus (Benth.) Roberty) (Lamiaceae) and Annona senegalensis Pers. (Annonaceae) are generally used for stored grain protection in northern Cameroon (Ngamo and Hance, 2007). $P$. glandulosus is used locally in folk medicine for the treatment of colds and sore throat 
(Ngassoum et al., 2001). Again, scientific evidences on the bioactivity of powders from this plant against insects are scanty. Nukenine et al. (2010a) reported good and modest insecticidal activity of $P$. glandulosus leaf powder against $S$. zeamais and Prostephanus truncatus (Horn) (Coleoptera: Bostrichidae), respectively, under fixed laboratory conditions (temperature: $25{ }^{\circ} \mathrm{C}$ and r.h.: $65-70 \%$ ). The medicinal properties of A. senegalensis are well documented, especially in the treatment of diarrhoea, dermatitis and gastric ulcers (Suleiman et al., 2008). The insecticidal properties of the plant are also reported (Ngamo and Hance, 2007), though with little information on its leaf powder and S. zeamais. Petroleum and ethanolic extracts, as well as powders from the leaves of Steganotaenia araliacea Hochst (Araliaceae) showed significant toxic and repellent effect against Tribolium castaneum (Herbst) (Coleoptera: Tenebrionidae) (Abubakar et al., 2001). The crude extracts of $S$. araliacea showed anthelmintic (Monglo et al., 2006) and antileishmanial activity (Ndjonka et al., 2010). There is a dearth of information about the insect control properties of $S$. araliacea and only one study has reported on $S$. zeamais (Nukenine et al., 2007).

Against this background, this paper presents the results of an investigation on the effects of seed powder from A. indica and leaf powders from $P$. glandulosus, A. senegalensis and $S$. araliacea as toxicants against adult $S$. zeamais. The ability of the plant materials to reduce damage and suppress population increase of the weevil was also examined. In addition, the paper highlights the outcomes of drying regime and particle size of $P$. glandulosus and S. araliacea leaf powders on toxicity to $S$. zeamais.

\section{MATERIALS AND METHODS \\ Culturing of insects}

Individuals of $S$. zeamais were obtained

from a laboratory stock culture, kept since
2005 at the Department of Applied Chemistry, University of Ngaoundere, Cameroon. Twenty adults of mixed sex were put in $900 \mathrm{ml}$ glass jars containing $500 \mathrm{~g}$ of disinfested maize of the var. Shaba harvested in Belel, Adamawa region, Cameroon in December 2006. The jars were covered with nylon mesh held in place with rubber bands. After two weeks of oviposition period, the adults were removed and the progeny that emerged later were used for the different assays. The ages of the insects were known to be 14-21 d.

\section{Collection and preparation of plant materials}

The ripe fruits of $A$. indica were collected on the ground under neem trees at Kaélé, Far North Region of Cameroon in November 2006. In the same month, the nonsenescent leaves of $A$. senegalensis, $P$. glandulosus and $S$. araliacea were collected in Ngaoundere, Adamawa Region, with the help of a botanist. Kaélé and Ngaoundere are located respectively in the Sudano-Sahelian and Sudano-Guinean agro-ecological zones. The Sudano-Sahelian agro-ecological zone is characterized by two seasons: wet (June to September) and dry (October to May) (IRAD, 2007). Annual rainfall ranges between 800 and $1000 \mathrm{~mm}$. Annual mean temperature is 29 ${ }^{\circ} \mathrm{C}$, with a maximum of $39{ }^{\circ} \mathrm{C}$ in March and minimum of $17{ }^{\circ} \mathrm{C}$ in January. Average annual relative humidity stands at $67 \%$. The Ngaoundere area is characterized by two seasons - a dry season from November to March and a wet season spanning April to October. Average annual temperature is $22^{\circ} \mathrm{C}$ with a maximum of $34{ }^{\circ} \mathrm{C}$ in March and a minimum of $12{ }^{\circ} \mathrm{C}$ in December or January. Annual precipitation is $1595 \mathrm{~mm}$ (Anonymous, 1981).

The neem fruits were hand-depulped and the seeds sundried for 5 days, before decortications to obtain the seed kernels. The leaves of A. senegalensis were dried under shade on laboratory tables for seven days, 
when they were crisp dry. Part of the leaves of $P$. glandulosus and S. araliacea was sundried for four days while the other part was dried under shade on laboratory tables for seven days. All the dried plant materials were pounded in a locally-manufactured wooden mortar. The crushed plant materials were passed through a 1-mm mesh sieve. In addition, part of the crushed leaves of $P$. glandulosus and $S$. araliacea dried under shade was further pounded until the powders passed through a $0.2-\mathrm{mm}$ mesh sieve. This two mesh sizes are popularly used by farmfamilies in the Northern Region of Cameroon. All the plant powders were stored in a refrigerator at $+4{ }^{\circ} \mathrm{C}$ until needed for bioassay.

\section{Adult mortality bioassay}

Four quantities $(0.25,0.5,1$ and $2 \mathrm{~g})$ of the powders dried under shade with particle size $1 \mathrm{~mm}$ for each plant species were separately admixed to $50 \mathrm{~g}$ of disinfested maize (var. Shaba) in $900 \mathrm{ml}$ glass jars to give the contents 5, 10, 20, and $40 \mathrm{~g} / \mathrm{kg}$, respectively. Each jar was then closed with a perforated metal lid. The powder extract plus grain was thoroughly hand mixed for $5 \mathrm{~min}$. Control for each set of treatments consisted of grain containing no plant material. Each treatment was repeated 3 times. A group of 20 adult $S$. zeamais of mixed sex, aged 2-3 weeks, was added into the jars containing the treated or untreated grains. Adult mortality was recorded 14 days after treatment

\section{Population increase and Damage}

The two middle contents 10 and 20 $\mathrm{g} / \mathrm{kg}$ as applied in the previous section of the shade-dried powder with 1-mm particle size from the four plant species for $100 \mathrm{~g}$ grain were prepared as described earlier. A group of 25 (2-3 weeks old) adult $S$. zeamais of mixed sex was introduced into each jar containing treated or untreated grain. Control for each set of treatments consisted of grain without plant material. Each treatment was repeated 3 times. After 3 months, the number of live insects was determined for each jar. Grain damage was determined by randomly selecting 100 grains from each jar and the number of damaged (grains with characteristic holes) and undamaged (without holes) grains were counted and weighed (Nukenine et al., 2010a). Another damage parameter, Weevil Perforation Index (WPI), was estimated as follows (Fatope et al., 1995):

$\mathrm{WPI}=(\%$ treated maize grains perforated $) /(\%$ control maize grains perforated)

WPI > 50: negative protectant of plant material tested (i.e. enhancement of infestation by the weevil)

WPI < 50: positive protectant (i.e. prevention of infestation by the weevil).

\section{Drying regime and particle size}

The powders of $P$. glandulosus and $S$. araliacea from the sun- and shade-dried leaves with particle size of $0.2 \mathrm{~mm}$ and $1 \mathrm{~mm}$ were used for this bioassay. Similar treatments like for the section on "Adult mortality" above was applied here. For drying regime, sun- and shade-dried leaves with particle size $0.2 \mathrm{~mm}$ were considered for the two plant species. Powders with particle size 0.2 and $1 \mathrm{~mm}$ from the shade-dried leaves of the two plants were used. The different powder contents were mixed with maize grains as described previously. A group of 20 (2-3 weeks old) adult $S$. zeamais of mixed sex was introduced into each jar containing treated or untreated grain. Control for each set of treatments consisted of grain without plant material. Each treatment was repeated 3 times. Adult mortality was recorded 30 days after treatment.

\section{Statistical analysis}

Percentage mortality data of $S$. zeamais adults were not corrected for control mortality, because mortality in the control 
treatment was $\leq 2 \%$ (Abbott, 1925). Data on $\%$ cumulative mortality and \% grain damage were arcsine-transformed [square $\operatorname{root}(\mathrm{x} / 100)]$ and the number of $S$. zeamais adults was $\log$ transformed $(\mathrm{x}+1)$. The transformed data were subjected to the ANOVA procedure using the statistical analysis system (SAS Institute 2003). Tukey studentized (HSD) test $(\mathrm{P}=0.05)$ was applied for mean separation.

\section{RESULTS}

\section{Adult mortality}

Mortality of $S$. zeamais was affected by powder content for treatments with $A$. indica and $P$. glandulosus, but not $A$. araliacea and A. senegalensis (Table 1). Control mortality was $\leq 2.0 \%$ and differed from all the treatments for A. indica and P. glandulosus, but with treatments $\geq 20 \mathrm{~g} / \mathrm{kg}$ for $S$. araliacea. The mortality caused to $S$. zeamais varied among the plant species and decreased in the following order: $P$. glandulosus $>$ A. indica $>$ A. senegalensis $=S$. araliacea . The highest tested content $(40 \mathrm{~g} / \mathrm{kg})$ of the leaf powder from $P$. glandulosus, A. indica, S. araliacea and $A$. senegalensis achieved $83 \%, 38 \%, 7 \%$ and $5 \%$ mortality of $S$. zeamais, respectively.

\section{Population increase and grain damage}

The rate of increase of the population of $S$. zeamais was greatly reduced by the plant powders, except for A. senegalensis (Table 2), especially for the higher content $(40 \mathrm{~g} / \mathrm{kg})$. However, the lower content $(20 \mathrm{~g} / \mathrm{kg})$ of $A$. indica and $S$. araliacea reduced the rate of population increase of $S$. zeamais 10 - and 2fold, respectively. The controls and the samples treated with $P$. glandulosus $(20 \mathrm{~g} / \mathrm{kg})$ and A. senegalensis (20 and $40 \mathrm{~g} / \mathrm{kg}$ ) had statistically similar numbers of live weevils after three months.

All the powders significantly reduced grain damage from the weevil attack, with the samples treated with 20 or $40 \mathrm{~g} / \mathrm{kg}$ of $A$. indica and $S$. aralicea, and $40 \mathrm{~g} / \mathrm{kg}$ of $P$. glandulosus and A. senegalensis recording a smaller number of damaged grains than the controls (Table 2). However, the WPI $(<10 \%)$ showed that only A. indica (20 and $40 \mathrm{~g} / \mathrm{kg}$ ) and $P$. glandulosus ( $40 \mathrm{~g} / \mathrm{kg}$ ) were effective in preventing infestation of the maize grains by S. zeamais.

\section{Drying regime and particle size}

Table 3 shows the percentage mortality of $S$. zeamais adults after exposure to increasing contents of powders from Shadedried and sun-dried leaves of $P$. glandulosus and $S$. araliacea for one month. Adult mortality was dose-dependent for $P$. glandulosus but not $S$. araliacea. The mortality of $S$. zeamais was not different between the shade-dried and sun-dried leaves for all the contents of $S$. araliacea and the lower contents (5 and $10 \mathrm{~g} / \mathrm{kg}$ ) for $P$. glandulosus powder. At powder contents of 20 and $40 \mathrm{~g} / \mathrm{kg}$ for P. glandulosus, the weevil mortality caused by the shade-dried powder was greater than that caused by the sun-dried powder. For these two contents, $47 \%$ vs. $12 \%$ and $68 \%$ vs. $22 \%$ mortality were achieved for the shade- and sun-dried powders of the plant, respectively.

Similarly, the adult mortality of $S$. zeamais was dose-dependent for $P$. glandulosus and not $S$. araliacea for the fineand coarse-particle powders (Table 4). Control mortality was lower than those of the treatments with powder contents $\geq 20 \mathrm{~g} / \mathrm{kg}$, regardless of plant species or particle size. At higher powder contents for $P$. glandulosus $(20$ and $40 \mathrm{~g} / \mathrm{kg}$ ) and $S$. araliacea $(40 \mathrm{~g} / \mathrm{kg})$, mortality caused by the fine powder to $S$. zeamais was higher compared with that caused by the coarse powder. 
Table 1: Mortality of adult Sitophilus zeamais exposed to four plant powders for two weeks.

\begin{tabular}{lccccc}
\hline \multirow{2}{*}{$\begin{array}{l}\text { Content } \\
(\mathbf{g} / \mathbf{k g})\end{array}$} & \multicolumn{3}{c}{ Plant powder \% mortality $($ mean $\pm \mathbf{S E})$} & \multirow{2}{*}{$\boldsymbol{F}_{(3,8)}$} \\
\cline { 2 - 5 } & $\begin{array}{c}\text { Azadirachta } \\
\text { indica }\end{array}$ & $\begin{array}{c}\text { Plectranthus } \\
\text { glandulosus }\end{array}$ & $\begin{array}{c}\text { Steganotaenia } \\
\text { araliacea }\end{array}$ & $\begin{array}{c}\text { Annona } \\
\text { senegalensis }\end{array}$ & \\
\hline 0 & $2 \pm 1.7 \mathrm{cA}$ & $2 \pm 1.7 \mathrm{dAB}$ & $0 \pm 0.0 \mathrm{bA}$ & $0 \pm 0.0 \mathrm{aA}$ & $0.7 \mathrm{~ns}$ \\
5 & $13 \pm 1.7 \mathrm{bA}$ & $10 \pm 0.0 \mathrm{cAB}$ & $2 \pm 1.7 \mathrm{abB}$ & $3 \pm 1.7 \mathrm{aAB}$ & $6.6^{*}$ \\
10 & $22 \pm 1.7 \mathrm{bA}$ & $40 \pm 2.9 \mathrm{bA}$ & $3 \pm 1.7 \mathrm{abB}$ & $3 \pm 1.7 \mathrm{aB}$ & $22.1^{* * *}$ \\
20 & $27 \pm 1.7 \mathrm{abB}$ & $65 \pm 5.8 \mathrm{aA}$ & $5 \pm 0.0 \mathrm{aC}$ & $5 \pm 2.9 \mathrm{aC}$ & $37.3^{* * *}$ \\
40 & $38 \pm 1.7 \mathrm{aB}$ & $83 \pm 4.4 \mathrm{aA}$ & $5 \pm 0.0 \mathrm{aC}$ & $7 \pm 1.9 \mathrm{aC}$ & $158.5^{* * *}$ \\
$F_{(4,10)}$ & $34.3^{* * *}$ & $71.0^{* * *}$ & $4.3^{*}$ & $2.1 \mathrm{~ns}$ & \\
\hline
\end{tabular}

Means in the same column followed by the same lowercase letter do not differ significantly; means in the same row followed by the same uppercase letter do not differ significantly at $\mathrm{P}<0.05$ (Tukey test). Each datum represents the mean of three replicates. ns $\mathrm{P}<0.05, * \mathrm{P}<0.05, * * * \mathrm{P}<0.001$.

Table 2: Population increase and damage parameters of Sitophilus zeamais in maize admixed with different contents of powders from four plant species and stored for three months.

\begin{tabular}{|c|c|c|c|c|}
\hline Plant species & $\begin{array}{c}\text { Content } \\
(\mathrm{g} / \mathrm{kg})\end{array}$ & $\begin{array}{l}\text { No. of insects } \\
(\text { mean } \pm \text { S.E. })\end{array}$ & $\begin{array}{c}\text { Damaged grains (\%) } \\
(\text { mean } \pm \text { S.E. })\end{array}$ & $\begin{array}{c}\text { Weevil Perforation } \\
\text { Index }(\%)\end{array}$ \\
\hline Azadirachta & 0 & $388 \pm 17.2 \mathrm{a}$ & $93 \pm 1.5 \mathrm{a}$ & \\
\hline \multirow[t]{3}{*}{ indica } & 20 & $31 \pm 9.2 b$ & $8 \pm 1.2 \mathrm{~b}$ & 8.6 \\
\hline & 40 & $6 \pm 1.7 \mathrm{c}$ & $3 \pm 1.2 \mathrm{c}$ & 3.2 \\
\hline & $F_{(2,6)}$ & $82.8^{* * * *}$ & $437.2 * * *$ & \\
\hline Plectranthus & 0 & $344 \pm 19.3 a$ & $91 \pm 1.3 \mathrm{a}$ & \\
\hline \multirow[t]{3}{*}{ glandulosus } & 20 & $221 \pm 18.1 \mathrm{a}$ & $80 \pm 6.1 \mathrm{a}$ & 87.9 \\
\hline & 40 & $21 \pm 3.4 b$ & $7 \pm 0.3 b$ & 7.7 \\
\hline & $F_{(2,6)}$ & $2079.7 * * *$ & $133.4 * * *$ & \\
\hline Steganotaenia & 0 & $313 \pm 6.6 a$ & $89 \pm 2.1 \mathrm{a}$ & 76.4 \\
\hline \multirow{3}{*}{ araliacea } & 20 & $145 \pm 6.8 b$ & $68 \pm 7.0 \mathrm{~b}$ & 60.7 \\
\hline & 40 & $183.7 \pm 7.7 \mathrm{c}$ & $54 \pm 4.5 b$ & \\
\hline & $F_{(2,6)}$ & $107.2 * * *$ & $14.1 * *$ & \\
\hline Annona & 0 & $274 \pm 7.8 \mathrm{a}$ & $87 \pm 1.9 a$ & \\
\hline \multirow[t]{3}{*}{ senegalensis } & 20 & $259 \pm 51.4 \mathrm{a}$ & $81 \pm 0.6 a b$ & 93.1 \\
\hline & 40 & $257 \pm 17.0 \mathrm{a}$ & $77 \pm 2.4 b$ & 88.5 \\
\hline & $F_{(2,6)}$ & $0.15 \mathrm{~ns}$ & $7.9^{*}$ & \\
\hline
\end{tabular}

Means in the same column followed by the same letter do not differ significantly at $\mathrm{P}<0.05$ (Tukey test). Each datum represents the mean of three replicates. $\mathrm{ns} \mathrm{P}<0.05$, $* \mathrm{P}<0.05$, *** $\mathrm{P}<0.001$. 
Table 3: Mortality of adult Sitophilus zeamais exposed to powders of Plectranthus glandulosus and Steganotaenia araliacea from shade- and sun-dried leaves for one month.

\begin{tabular}{|c|c|c|c|c|}
\hline \multirow[t]{2}{*}{ Plant species } & \multirow[t]{2}{*}{ Content $(\mathrm{g} / \mathrm{kg})$} & \multicolumn{2}{|c|}{$\begin{array}{c}\text { Drying regime } \\
\% \text { Mortality (Mean } \pm \text { S.E.) }\end{array}$} & \multirow[t]{2}{*}{$t$-value } \\
\hline & & Shade & Sun & \\
\hline \multirow[t]{6}{*}{ P. glandulosus } & 0 & Od & Ob & \\
\hline & 5 & $13 \pm 3.3 c$ & $3 \pm 2.9 b$ & $2.9 \mathrm{~ns}$ \\
\hline & 10 & $15 \pm 2.9 c$ & $8 \pm 5.8 \mathrm{ab}$ & $1.5 \mathrm{~ns}$ \\
\hline & 20 & $47 \pm 1.7 b$ & $12 \pm 1.7 \mathrm{ab}$ & $14.8 * * *$ \\
\hline & 40 & $68 \pm 3.3 a$ & $22 \pm 4.4 \mathrm{a}$ & $8.4 * *$ \\
\hline & $F_{(4,10)}$ & $128.2 * * *$ & $7.1 * *$ & \\
\hline \multirow[t]{6}{*}{ S. araliacea } & 0 & $\mathrm{Ob}$ & $\mathrm{Ob}$ & \\
\hline & 5 & $5 \pm 2.9 \mathrm{ab}$ & $7 \pm 1.7 a$ & $-0.5 \mathrm{~ns}$ \\
\hline & 10 & $8 \pm 1.7 \mathrm{ab}$ & $7 \pm 1.7 a$ & $0.7 \mathrm{~ns}$ \\
\hline & 20 & $15 \pm 2.9 \mathrm{a}$ & $8 \pm 1.7 a$ & $2.0 \mathrm{~ns}$ \\
\hline & 40 & $18 \pm 3.3 \mathrm{a}$ & $12 \pm 1.7 \mathrm{a}$ & $1.8 \mathrm{~ns}$ \\
\hline & $F_{(4,10)}$ & $5.9^{*}$ & $24.0 * * *$ & \\
\hline
\end{tabular}

Means in the same column followed by the same letter do not differ significantly at $\mathrm{P}<0.05$ (Tukey test). Each datum represents the mean of three replicates. ns $\mathrm{P}<0.05$, $* \mathrm{P}<0.05$, ** $\mathrm{P}<0.01$, *** $\mathrm{P}<0.001$.

Table 4: Mortality of adult Sitophilus zeamais exposed to powdered leaves of Plectranthus glandulosus and Steganotaenia araliacea with fine and coarse particles for one month.

\begin{tabular}{|c|c|c|c|c|}
\hline \multirow[t]{3}{*}{ Plant species } & \multirow[t]{3}{*}{ Content (g/kg) } & \multirow{2}{*}{\multicolumn{2}{|c|}{$\begin{array}{c}\text { Particle size } \\
\% \text { Mortality }(\text { mean } \pm \text { S.E. })\end{array}$}} & \multirow[t]{3}{*}{$t$-value } \\
\hline & & & & \\
\hline & & Fine $(0.2 \mathrm{~mm})$ & Coarse $(1.0 \mathrm{~mm})$ & \\
\hline \multirow[t]{6}{*}{ P. glandulosus } & 0 & $0 \mathrm{c}$ & 0 & \\
\hline & 5 & $7 \pm 3.3 b c$ & $13 \pm 1.7 c$ & $-1.8 \mathrm{~ns}$ \\
\hline & 10 & $18 \pm 1.7 b$ & $14 \pm 1.7 \mathrm{c}$ & $2.1 \mathrm{~ns}$ \\
\hline & 20 & $62 \pm 4.4 a$ & $23 \pm 1.7 b$ & $8.1^{* *}$ \\
\hline & 40 & $68 \pm 4.4 a$ & $38 \pm 3.3 \mathrm{a}$ & $5.4 * *$ \\
\hline & $F_{(4,10)}$ & $55.4 * * *$ & $30.8 * * *$ & \\
\hline \multirow[t]{6}{*}{ S. araliacea } & 0 & $0 \mathrm{c}$ & $0 \mathrm{~b}$ & \\
\hline & 5 & $10 \pm 1.9 b$ & $12 \pm 1.7 \mathrm{a}$ & $-0.5 n s$ \\
\hline & 10 & $17 \pm 3.3 \mathrm{ab}$ & $15 \pm 2.9 \mathrm{a}$ & $0.4 \mathrm{~ns}$ \\
\hline & 20 & $15 \pm 2.9 b$ & $15 \pm 2.9 a$ & $0.0 \mathrm{~ns}$ \\
\hline & 40 & $30 \pm 2.9 a$ & $18 \pm 1.7 \mathrm{a}$ & $3.5^{*}$ \\
\hline & $F_{(4,10)}$ & $106.5 * * *$ & $10.6^{* *}$ & \\
\hline
\end{tabular}

Means in the same column followed by the same letter do not differ significantly at $\mathrm{P}<0.05$ (Tukey test). Each datum represents the mean of three replicates. $\mathrm{ns} \mathrm{P}<0.05, * \mathrm{P}<0.05, * * \mathrm{P}<0.01$, *** $\mathrm{P}<0.001$. 


\section{DISCUSSION}

Our investigations showed a high insecticidal efficacy of $P$. glandulosus powder against adult $S$. zeamais, but much lower efficacy for A. indica powder and practically no activity for $A$. araliacea and $A$. senegalensis, within 14-d exposure period. Koona and Njoya (2004) contented that powdered dried leaves of plants can cause death through desiccation of insects or through occlusion of their spiracles, thereby preventing respiration via the tracheal system. These mechanisms are not in line with the findings of the present study, because even at the highest powder content of $40 \mathrm{~g} / \mathrm{kg}, S$. araliacea and A. senegalensis recorded $<8 \%$ and A. indica only $38 \%$ mortality of the weevil. $P$. glandulosus which is more aromatic than the other plants caused a much higher mortality of $83 \%$ to S. zeamais within the 14-d exposure period. Furthermore, Golob (1997) demonstrated that dusts are only effective in killing insects through desiccation when the particles are very small. The particle size in the present study was large $(1 \mathrm{~mm})$. It therefore appears more plausible to attribute the toxicity of the powders to their volatile components which are dominated by monoterpenoids in the case of $P$. glandulosus, $S$. araliacea and A. senegalensis (Jirovetz et al., 2002; Nukenine et al., 2007). Weaver et al. (1995) attributed the very significant insecticidal activity of the leaf powders from two aromatic plants (Artemesia tridentata (Nutt.) and Monarda fistulosa L.) against Zabrotes subfasciatus (Boheman) (Coleoptera: Bruchidae) to the liberation of highly volatile terpenoid compounds by powdering. The leaf essential oil from $P$. glandulosus collected in Ngaoundere, Cameroon in July 2004 was rich in cispiperitone (19.5\%), fenchone (18.3\%), piperitone oxide $(17.9 \%)$, piperitone $(8.9 \%)$ and terpinolene $(8.2 \%)$ (Nukenine et al., 2007). Park et al. (2003) found terpinolene to be highly toxic to Sitophilus oryzae (L.) and Callosobruchus chinensis (L.) (Coleoptera: Bruchidae). Nukenine et al. (2010b) also demonstrated high toxicity of fenchone on coated maize grains to $S$. zeamais. Concerning the mode of action of monoterpenes, Ryan and Byrne (1988) suggested that the toxic effect may be attributed to reversible competitive inhibition of acetylcholinesterase by occupation of the hydrophobe site of the enzyme's active centre.

Under fixed laboratory condition of 25 ${ }^{\circ} \mathrm{C}$ and 60-65\% r.h., powdered leaves (500 $\mu \mathrm{m})$ of $P$. glandulosus collected in October 2004 at Ngaoundere and applied at the rate of $40 \mathrm{~g} / \mathrm{kg}$ on grains caused $88 \%$ mortality to $S$. zeamais within 14-d, which accords with the $83 \%$ mortality recorded in the present study under uncontrolled laboratory conditions (Nukenine et al., 2010a). In a related study carried out under same conditions, leaf powders of $P$. glandulosus and $S$. araliacea collected in July 2004, achieved respectively $81 \%$ and $30 \%$ mortality of $S$. zeamais within 8 days, and $100 \%$ and $65 \%$ within 16 days (Nukenine et al., 2007). This indicates a better activity of the two plant powders than in the present study where leaf collection was done in November 2006. This suggests that $P$. glandulosus collected earlier in the season may be richer in volatile terpenoids compared to that collected later in the season. It suggests also that the insecticidal activity of $S$. araliacea may be affected more by environmental conditions than that of $P$. glandulosus. There is thus the need of testing the insecticidal activity of botanical powders under different environmental conditions in order to validate their use in stored grain 
protection. Nonetheless, the results from studies that assess the efficacy of botanicals under uncontrolled laboratory conditions would be more meaningful in the protection of grains in subsistence agriculture, where grains are stored under unaltered environmental conditions.

The low mortality of the weevil recorded by $A$. indica seed powder within 14d was not surprising because its constituents, including the dominant azadirachtin, a tetranotriterpenoid limonoid, possess antifeedant, repellant, growth disrupting and larvicidal properties against a large number of pests (Schmutterer, 1990; Aerts and Mordue, 1997; Mathur, 2013). The antifeedant mechanism takes a longer time to cause high or complete mortality to insects, and it is thought to be the dominant mode of action in the present study. This antifeedant mechanism and the other modes of action of A. indica powder stated above gain further support from the results of our study on population increase and grain damage, where the plant was by far the most effective. Indeed, $A$. indica powder at the rates of $20 \mathrm{~g} / \mathrm{kg}$ and $40 \mathrm{~g} / \mathrm{kg}$ reduced the rate of $S$. zeamais population increase 12 - and 65-fold, respectively, confirming its potential as a grain protectant against insects. The grain protectant ability of $A$. indica seed powder is re-enforced by the very low percentage damaged grains and WPI recorded by the grains treated with this powder. A. indica seed powder at the rate of $15 \mathrm{~g} / \mathrm{kg}$ was effective in protecting bean seeds against the infestation of Acanthoscelides obtectus (Say) (Coleoptera: Bruchidae) and Z. fasciatus under farm conditions (Paul et al., 2009). This corroborates the results of this study considering that A. indica seed powder at 20 $\mathrm{g} / \mathrm{kg}$ greatly protected maize grains against the infestation of $S$. zeamais.
Azadirachta indica seed powder is rich in oil and leaves the treated grains with a pungent smell and off-taste, which are difficult to remove. The aromatic $P$. glandulosus leaf powder is easy to remove from the grains and leaves very little smell and only slightly altered taste to the grains which could be washed away with less effort. Farmers in Tanzania who protected their grains with Chenopodium ambrosiodes L. (Chenopodiaceae) complained about the pungent smell and bad taste of the cooked beans (Paul et al., 2009). P. glandulosus leaf powder therefore stands a good chance for adoption in the protection of both food and seed grains against insect infestation, while $A$. indica seed powder would be more attractive for the protection of seed grains and less adopted for food grains.

The higher efficacy of fine-particlepowder from $P$. glandulosus against adult $S$. zeamais compared with the coarse-particlepowder was not surprising because smaller particle size implies better liberation of volatile insecticidal terpeinoids compounds from the leaves (Weaver et al., 1995). Asawalam and Emosairue (2006) recorded also better efficacy of smaller particles (0.6 $\mathrm{mm}$ ) of $P$. guineense powder against $S$. zeamais compared to the larger particles (2 $\mathrm{mm})$. The smaller particle powder of $P$. glandulosus could also be effective against $S$. zeamais through dessication. Golob (1997) demonstrated that dusts are only effective in killing insects through desiccation when the particle size is very small. Exposure of botanicals to sunlight may lead to photodegradation and thermo-degradation (Jenkins et al., 2003; Ilboudo et al., 2010). This is thought to be the major reason why the powders from sun-dried $P$. glandulosus leaves 
were less effective against $S$. zeamais than that from the shade-dried leaves.

Based on the good efficacy of powders from $P$. glandulosus leaves and A. indica seeds in protecting maize against the infestation of the noxious $S$. zeamais indicated in the present study and because they are available, easy to prepare and environmentally safe and friendly, a wide use of these botanicals is recommended for the control of the economically important $S$. zeamais. It is also recommended to use powders from shade-dried plant parts, with smaller particles $(0.2 \mathrm{~mm})$ rather than sundried parts, with larger particles.

\section{ACKNOWLEDGEMENTS}

The work was supported by a Return Fellowship grant from the Alexander von Humboldt Foundation (AvH), Bonn, Germany to the first Author. The manuscript was written while the first author was on a research visit to the Federal Research Centre for Cultivated Plants - Julius Kühn Institut, Institute of Ecological Chemistry, Plant Analysis and Stored Product Protection, Berlin, Germany under the financial support of the AvH. We thank the Food for Progress 2004 Project of the United States Department of Agriculture through the International Institute of Tropical Agriculture, Yaoundé, Cameroon for providing additional financial support and field sites. Sincere gratitude to Professor P.-M. Mapongmetsem (botanist) of the Department of Biological Sciences, University of Ngaoundere, for guidance during the collection of the leaves.

\section{REFERENCES}

Abbott WS. 1925. A method of computing the effectiveness of an insecticides. J. Econ. Entomol., 18: 265-267.
Abubakar MS, Abdurahman EM, Nock IH, Haruna AK, Garba M. 2001. The evaluation of pest control properties of Steganotaenia araliacea. J. Herbs Spices Medic. Plants, 8: 51-57.

Aerts RJ, Mordue AJ. 1997. Feeding deterrence and toxicity of neem triterpenoids. J. Chem. Ecol., 23: 21172132.

Anonymous 1981. Encyclopédie de la République Unie du Cameroun (Tome 1). Nouvelles Edition Africaines : Douala.

Asawalam EF, Emosairue SO. 2006. Comparative efficacy of Piper guineense (Schum and Thonn) and Pirimiphos Methyl as poisons against Sitophilus zeamais (Motsch.). Electron. J. Environ. Agric. Food Chem., 5(5): 1536-1545.

Chaube MK. 2008. Fumigant toxicity of essential oils from some common spices against pulse beetle, Callosobruchus chinensis (Coleoptera: Bruchidae). J. Oleo. Sci., 57: 171-179.

FAO. 2011. FAOSTAT for 2011. Food and Agricutural organization of the United Nations: Rome.

Fatope MO, Nuhu AM, Mann A, Takeda Y. 1995. Cowpea weevil bioassay. A simple prescreen for plant with grain protectant effects. Int. J. Pest Manag., 41: 84-86.

Golob P. 1997. Current status and future perspectives for inert dusts for control of stored product insects. J. Stored Prod. Res., 33: 69-79.

Ilboudo Z, Dabiré LCB, Nébié RCH, Dicko IO, Dugravot S, Cortesero AM, Sanon A. 2010. Biological activity and persistence of four essential oils towards the main pest of stored cowpeas, Callosobruchus maculatus (F.) (Coleoptera: Bruchidae). J. Stored Prod. Res., 46: 124-128. 
IRAD. 2007. Revue Scientifique 2007 de l'IRAD. Institute of Agriculrural Research for Development : Yaoundé.

Isman MB. 2006. Botanical insecticides, deterrents and repellents in modern agriculture and an increasingly regulated world. Ann. Rev. Entomol., 51: 45-66.

Jembere B, Obeng-Ofori D, Hassanali A. 1995. Products derived from the leaves of Ocimum kilimandscharicum (Labiatae) as post-harvest grain protectants against the infestation of three stored product insect pests. Bull. Entomol. Res., 85: 361-367.

Jenkins DA, Dunkel FV, Gamby KT. 2003. Storage temperature of neem kernel extract: differential effects on oviposition deterrency and larval toxicity of Callosobruchus maculatus (F.) (Coleoptera: Bruchidae). Environ. Entomol., 32: 1283-1289.

Jirovetz L, Buchauer G, Ngassoum MB, Mapongmetsem PM. 2002. Analysis of the Aroma compounds of fruit and leaf essential oils of Annona senegalensis from Cameroon using GC-FID, GC-MS, and olfactometry. Ernährung/Nutrition, 26: 205-209.

Koona P, Njoya J. 2004. Effectiveness of soybean oil and powder from leaves of Lantana camara Linn. (Verbenaceae) as protectants of stored maize against infestation by Sitophilus zeamais Motsch. (Coleoptera: Curculionidae). Pakistan. J. Biol. Sc., 7: 2125-2129.

Mathur S. 2013. Biopesticidal activity of Azadirachta indica A Juss. Res. J. Pharm. Biol. Chem. Sc., 4(2): 1131-1136.

Monglo D, Njongmeta LM, Musongong G, Ngassoum M, Nukenine EN. 2006. Evaluation of anthelmintic potential of ethanolic plant extracts from Northern Cameroon against eggs and infective larvae of Haemonchus contortus. J. Biol. Sci., 6: 426-433.

Mordue AJ, Blackwell A. 1993. Azadirachtin: an update. J. Insect Physiol., 39: 903924.

Napaleao TH, Belmonte BDR, Pontual EV, Albuquerque de LP, Sa RA, Paiva LM, Coelho LCBB, Paiva PMG. 2013. Deleterious effects of Myracrodruon urundeuva leaf extract and lectin on maize weevil, Sitophilus zeamais (Coleopera: Curculionidae). J. Stored Prod. Res., 54: 26-33.

Ndjonka D, Agyare C, Lüersen K, Hensel A, Liebau E. 2010. In vitro anti-leishmanial activity of traditional medicinal plants from Cameroon and Ghana. Int. J. Pharmacol., 6(6): 863-871.

Ngamo LST, Hance T. 2007. Diversité des ravageurs des denrées et méthodes alternatives de lutte en milieu tropical. Tropicultura, 25: 215-220.

Ngassoum MB, Jirovetz L, Buchbauer G, Fleischlacker W. 2001. Investigation of Essential Oils of Plectranthus glandulosus Hook. (Lamiacée) from Cameroon. J. Ess. Oil Res., 13: 73-75.

Noumi E, Anguessin B. 2010. Insecticides and ethnomedicine of HIV/AIDS at Tokombere (Far North Cameroon). Indian J. Trad. knowl., 9: 730-735.

Nukenine EN, Adler C, Reichmuth Ch. 2007. Efficacy evaluation of plant powders from Cameroon as post-harvest grain protectants against the infestation of Sitophilus zeamais Motschulsky (Coleoptera: Curculionidae). J. Plant Dis. Prot., 114: 30-36.

Nukenine EN, Adler C, Reichmuth Ch. 2010a. Efficacy of Clausena anisata and Plectranthus glandulosus leaf powder against Prostephanus truncatus 
(Coleoptera: Bostrichidae) and two strains of Sitophilus zeamais (Coleoptera: Curculionidae) on maize. J. Pest Sci., 83: 181-190.

Nukenine EN, Adler C, Reichmuth Ch. 2010b. Bioactivity of fenchone and Plectranthus glandulosus oil against Prostephanus truncatus and two strains of Sitophilus zeamais. J. Appl. Ent., 134: 132-141.

Nukenine EN, Monglo B, Awasom I, Tchuenguem FFN, Ngassoum MB. 2002. Farmers' perception on some aspects of maize production, and infestation levels of stored maize by Sitophilus zeamais in the Ngaoundere region of Cameroon. Cameroon J. Biol. Biochem. Sci., 12: 1830.

Obeng-Ofori D. 2007. The use of botanicals by resource poor farmers in Africa and Asia for the protection of stored agricultural products. Stewart Postharvest Rev., 3: 1-8.

Park IK, Lee SG, Choi DH, Park JK, Ahn YJ. 2003. Insecticidal activities of constituents identified in the essential oil from leaves of Chamaecyparis obtusa against Callosobruchus chinensis (L.) and Sitophilus oryzae (L.). J. Stored. Prod. Res., 39: 375-384.

Paul VP, Lossini JS, Edwards PJ, Hilbeck A. 2009. Effectiveness of products from four locally grown plants for the management of Acanthoscelides obtectus (Say) and Zabrotes subfasciatus (Boheman) (both Coleoptera: Bruchidae) in stored beans under laboratory and farm conditions in Northern Tanzania. J. Stored. Prod. Res., 45: 97-107.

Philips TW, Throne JE. 2010. Biorational approaches to managing stored-product pests. Ann. Rev. Entomol., 55: 375-397.
Reichmuth Ch, Schöller M, Ulrichs C. 2007. Stored Products Pests in Grain. Morphology, Biology, Damage and control. Agro Concept Verlagsgesellschaft: Bonn; 170 p.

Ryan MF, Byrne O. 1988. Plant insect coevolution and inhibition of acetylcholinerase. J. Chem. Ecol., 14: 1965-1975.

SAS 2003. The SAS System Version 9.1 for Windows. SAS Institute: Cary, NC.

Schmutterer H. 1990. Properties and potentials of natural pesticides from neem tree. Annu. Rev. Entomol., 35: 271-298.

Suleiman MM, Dzenda J, Sani CA. 2008. Antidiarrhoel activity of the methanol stem-bark extract of Annona senegalensis Pers. (Annonaceae). J. Ethnopharmacol., 116: $125-130$.

Tapondjou AL, Bouda H, Fontem DA, Zapfack L, Lontsi D, Sondengam BL. 2000. Local plants used for traditional stored product protection in the Menoua division of the Western Highlands of Cameroun. IOBC Bull., 23: 73-77.

Tefera T, Kanampiu F, De Groote H, Hellin J, Mugo S, Kimenju S, Beyene Y, Boddupalli PM, Shiferaw B, Banziger M. 2011. The metal silo: an effective grain storage technology for reducing postharvest insect and pathogen losses in maize while improving smallholder farmers' food security in developing countries. Crop Prot., 30: 240-245.

Ukeh DA, Umoetok SBA, Bowman AS, Mordue (Luntz) AJ, Pickett JA, Birkett MA. 2012. Alligator pepper, Afromomum melegueta, and ginger, Zingiber officinale, reduce stored maize infestation by maize weevil, Sitophilus zeamais in traditional African granaries. Crop Prot., 32: 99-103. 
Weaver DK, Subramanyam B. 2000. Botanicals. In: Alternatives to Pesticides in Stored-Product IPM, Subbramanyam B, Hagstrum DW (eds). Kluwer: London; 303-320.

Weaver DK, Philips TW, Dunkel FV, Weaver T, Grubb RT, Nance EL. 1995. Dried leaves from rocky mountain plants decrease infestation by stored-product beetles. J. Chem. Ecol., 21 : 127-142.

Yengué JL, Callot Y. 2002. L'arbre et la ville dans la région de Maroua (l'ExtrêmeNord Cameroun). Sécheresse 13: 157162.
Yuya AI, Tadesse A, Azerefegne F, Tefera T. 2009. Efficacy of combining Niger seed oil with malathion $5 \%$ dust formulation on maize against the maize weevil, Sitophilus zeamais (Coleoptera: Curculionidae). J. Stored Prod. Res., 45: 67-70.

Zhao NN, Zhou L, Liu ZL, Du SS, Deng ZW. 2012. Evaluation of the toxicity of essential oils of some common Chinese spices against Liposcelis bostrychophila. Food Cont., 26: 486-49. 